麹のリパーゼ活性に及ぼす培地成分の影響 †

\section{国本正彦*・星野 保**・金庭正樹*}

Effect of Medium Components on Lipase Activity in "Koji"

Masahiko Kunimoto*, Tamotsu Hoshino** and Masaki Kaneniwa*

* Shimonoseki University of Fisheries, 2-7-1, Nagatahoncho, Shimonoseki-shi, Yamaguchi, 759-65

** Faculty of Fisheries, Hokkaido University, 3-1, Minato-cho, Hakodate-shi, Hokkaido, 041

Lipase activity were examined in "Rice koji", "Soybean koji", "Okara koji" and "Sardine koji", molded with Aspergillus oryzae. "Soybean koji", "Okara koji" and "Sardine koji" exhibited the lipase activity, while, the activity was negligible in "Rice koji".

Futhermore, effect of olive oil and pepton on the lipase activity was examined by using a mycelium. When $A$. oryzae was cultivated in the malt extract-dextrose medium, the lipase activity was not detectable. While, when the mycelium subsequently cultivated in the medium containing pepton, the lipase activity was high, but low in the medium containing olive oil. Lipase activity was mainly influenced by the nitrogenous compound in 'Koji' such as pepton.

(Received May 1, 1990)

イワシミールに Aspergillus oryzae を接種して製 翅した趃は製数前に比べ脂質含量が著しく減少する。こ れは製匐中にミールの脂質がこの菌により分解されたた めであり，この脂質の分解にはリパーゼが関与している ことを既に報告しだ，一方，趋のリパーゼに関する報 告は少なく，豆みそについての岡田ら゙2 とみそ玉埸につ

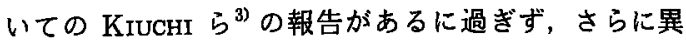
なる基質を用いた趣のリパーゼを検討した研究はみあた
らない，そこで，本研究では成分の異なる米，大豆，才 カラおよびイワシミールを基質として A. oryzae IF0 4202 を接種して製敖し，基質の成分之数のリパーゼ活 性との関係について検討し，さらに，リパーゼ活性の発 現に及ぼす脂質とタンパク質関連物質としてのペプトン の影響について検討した.

\section{1. 実験方法}

1. 供試菌株之製䟇

供試菌株は Aspergillus oryzae IFO 4202 株を用い た. 米数の製趜は 1986 年長野県産多用途米破砕精米 （精白度 90\%）を一晚水に浸せきした後，水切りし， $120^{\circ} \mathrm{C}, 30$ 分間加熱隇菌したものに供試菌を接種して 28 ${ }^{\circ} \mathrm{C}$ で培養することにより行った. 大豆数は 1986 年産十 勝大豆（豊鈴）を水に浸せきし，重量が 1.5 倍になるま で吸水させたすのを $120^{\circ} \mathrm{C}, 20$ 分間蒸募した。このるの をチョッパー（5 mm スクリーン）を通して造粒し, $120^{\circ} \mathrm{C}, 30$ 分間加熱隇菌後, 供試菌を振種し, $28^{\circ} \mathrm{C}$ で製 数した. オカラ翅は乾燥オカラ（みすず豆腐株式会社製） を水分含量 $50 \%$ になるよう加水した後, $120^{\circ} \mathrm{C}, 30$ 分 間加熱隇菌し，供試菌を接種して $28^{\circ} \mathrm{C} て ゙$ 製埸した. 1 ワシ数は，前報 ${ }^{1-}$ と同様に製麹した。

\section{A. oryzae の培盖}

麦芽エキスーグルコース培地で $28^{\circ} \mathrm{C}, 48$ 時間振とう培 養して菌系体を調製した．この菌系体を，脂質を含む培 地で培養する場合は，ッァペックードック培地から糖を 除いた培地に移植して $28^{\circ} \mathrm{C}, 6$ 時間前培養を行った後,

脂質濃度 $2.5 \%$ になるよう $3 \%$ のポリビニルアルコール で乳化した $25 \%$ とオリーブ油乳化液を添加して，さら に培養した．菌系体をペプトンを含む培地で培養する場 合は, ッァペックードック培地から硝酸ナトリウムを除 いた培地で 6 時開前培養した後, ペプトン濃度 $1 \%$ にな るようにペプトンを添加して，さらに培養した。このと き, $2.5 \mathrm{~g}$ の湿菌系体を $50 \mathrm{ml}$ の培地で培養した.

3. リパーゼの抽出とリパーゼ活性の測定

前報 ${ }^{1)}$ と同様に， $5 \mathrm{~g}$ を蒸留水 $15 \mathrm{~m} l$ ととあに水 冷下で 5 分間ホモジナイズした後，5ㄷ

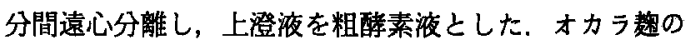
場合は，敖 $5 \mathrm{~g}$ に蒸留水 $15 \mathrm{~m} l$ を加え，海砂とともに 乳鉢で 15 分間磨砕し，ガーゼでろ過して得たろ液を遠 心分離し，上澄液を粗醉素液とした。 また，培養液の場 合は，培地を菌糸体ととあに水冷下で 5 分間ホモジナイ

$\dagger$ Aspergillus oryzae のリパーゼに関する研究（第 2 報）(前報, 文献 1)）

* 水産大学校 (厂759-65 山口県下関市吉見永田本町 1944)

** 北海道大学水産学部 (T041 北海道函館市港町 3-1-1) 
ズしこれを東洋ろ紙 No. 2 でろ過し，得られたろ液 を粗酵素とした，リパーゼ活性の測定は前報と同様に DOLE の方法" に準抛して行い，生成した脂肪酸を中和 するために要した $0.01 \mathrm{~N} \mathrm{NaOH} の \mathrm{~m} l$ 数を見掛けの リパーゼ活性とした。

\section{2. 桔果および考察}

基質として成分の異なる米，大豆，オカラおよびイワ シミールを原料として製赹した埸のリパーゼ活性を Table 1 に示した.この結果から大豆，オカラおよび イワシミールの题には高いリパーゼ活性が認められたが， 米数では殆じ認められなかった。 リパーゼ活性の弱い米 翅の基質である米の成分を大豆，オカラおよびイワシミ 一ルの成分と比較すると，米では炭水化物が主成分で夕 ンパク質が少なく，脂質は殆ど含まれていない゙，この ことから，基質成分の脂質またはタンパク質関連物質が リパーゼ活性の発現に影響しているあのと推察された。

そこで，さらにタンパク質関連物質としてペプトンを脂 質としてオリーブ油を添加した培地でリパーゼ活性に及 ぼすぺプトンとオリーブ油の影響を検討した．

まず，麦芽エキスーグルコース培地で $25^{\circ} \mathrm{C} ， 72$ 時間振

Table 1 Lipase activity in some kinds of materials molded, "Koji"

\begin{tabular}{ccccc}
\hline \hline \multirow{2}{*}{$\begin{array}{c}\text { Molding } \\
\text { time (h) }\end{array}$} & \multicolumn{4}{c}{ Materials } \\
\cline { 2 - 5 } & Rice & Soybean & Okara & Sardine meal \\
\hline 48 & 0.5 & 1.3 & 9.2 & 9.3 \\
72 & 0.6 & 5.1 & 4.4 & 2.9 \\
96 & 0.5 & 2.2 & 3.0 & 2.2 \\
\hline
\end{tabular}

Materials were molded for 48,72 and 96 hours at $28^{\circ} \mathrm{C}$. Crude enzyme was prepared as follow; $5 \mathrm{~g}$ of "Rice, soybean and sardine koji" was homogenized with $15 \mathrm{ml}$ of water, respectively. After subsequent centrifugation, the supernatant was obtained as crude enzyme. For "Okara koji", $5 \mathrm{~g}$ of "Koji", $15 \mathrm{ml}$ of water and sea sand were homogenized in mortar, and then homogenate was filtered through gauze. Futhermore, this filtrate was centrifuged as the same manner as the mentioned above. Enzymic reaction was carried out in the medium containing $2 \mathrm{ml}$ of olive oil emulsion, $1 \mathrm{ml}$ of $0.4 \mathrm{M}$ phosphate buffer $(\mathrm{pH} 7.0$ ) and $1 \mathrm{~m} l$ of crude enzyme at $37^{\circ} \mathrm{C}$ for 60 minutes, and activity was presented as milliliters of $0.01 \mathrm{~N} \mathrm{NaOH}$ required for titrate the free fatty acid liberated from substrate.
とう培養して菌系体を調製したが，この培地での培養で は菌系体にも培地にあリパーゼ活性は認められなかった。 このリパーゼ活性のない菌系体を、ッァペックードック 培地の硝酸ナトリウムの代わりにペプトンを $1 \%$ になる ように添加した培地とグルコースの代わりに $2.5 \%$ にな るようにオリーブ油を添加した培地に移し，さらに25 ${ }^{\circ} \mathrm{C}$ で培養した結果を Fig. 1 に示した. 脂質を添加した 場合もぺプトンを添加した場合もりパーゼ活性が発現し た。しかし，脂質を添加した場合のリパーゼ活性は弱か った．微生物のリバーゼ生産に及ぼす脂質の影暜につい ては, 脂質の添加がりパーゼ生産を誘導する場合 7 10) と，反対に，阻害する場合がある ${ }^{11122}$. A. oryzae で は培地への脂質の添加によるリパーゼ生産の阻害はなか ったが，促進も殆ど認められなかった。ペプトンを添加 した場合には活性が強く，窒素源としてのペプトンがリ パーゼ活性の発現に大きく関与していた，一般に微生物 のリパーゼ生産には窒素源濃度の高い培地が用いられる

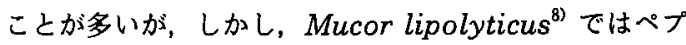
トンがリパーゼの生産を阻害することが報告されており， 微生物によりリパーゼ生産に及ぼすぺプトンの影響が異 なるあのと考えられる.A. oryzae ではタンパク質関 連物質であるぺプトンがリパーゼの生産を促進すること から，米靝ではリパーゼ活性が弱く，大豆，オカラおよ びイワシミールの静でリパーゼ活性が強いのは基質の夕

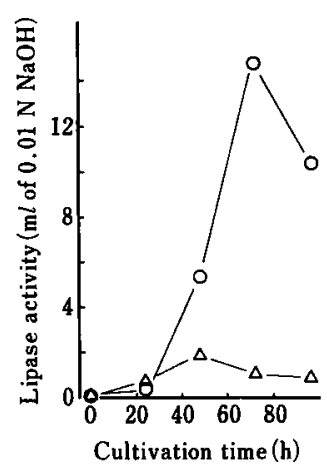

Fig. 1 Effects of olive oil and pepton on lipase activity in Aspergillus oryzae Crude enzyme was prepared to homogenize the medium togather with mycelium, and filtered through Toyo No. 2 filter paper. Lipase activity was assayed in the same manner as shown in Table 1.

$\mathrm{O}-\mathrm{O}$ : pepton added,

$\triangle \longrightarrow \triangle$ : olive oil added. 
ンパク質関連物質の影響であると推察される.

\section{3. 要 約}

米，大豆，オカラおよびマイワシミールを基質にした 趜のリパーぜ活性を調べた結果, 大豆, オカラおよびマ イワシ趎ではリパーゼ活性が高かったが, 米趎では活性 は殆じ認められなかった。 また, Aspergillus oryzae のリパーゼ活性の発現に及に゙す培地中の脂質とペプトン の影響を検討した結果, 培地中へのペプトンの添加によ りリパーゼ活性が発現した。この結果から，赹中のリパ 一ゼ活性の発現には原料中のタンパク質関連物質が影䭗 しているものと推察した。一方，リパーゼ活性の発現へ の脂質の影響はペプトンの場合に比べ小さかった.

本研究を行うにあたり，終始有益な御助言を睗った北 海道大学水産学部信濃晴雄教授ならびに東海物産株式会 社食品研究所長望月 務博士に心より謝意を表す. 本研 究は小森記念財団学術研究助成金に依った。

\section{文献}

1）国本正彦・星野 保-中野道紀：日水誌，55, 1097 (1989).
2）岡田安司・横尾良夫-竹内徳男：日食工誌，22, 379 (1975).

3) Kiuchi, K., Ohta, T. and Ebine, H.: J. Ferment. Technol., 53, 869 (1975).

4）藤井節郎・奥田拓道 : 脂質代謝実験法，(共立出 版, 東京), p. 137 (1967).

5）科学技術宁資源調查会編：四訂日本食品成分表， (大蔵省印刷局，東京), p. 50, 98-100，108 (1982)

6) Ohta, Y., Suzuki, M. and Yamada, K.: Agr. Biol. Chem., 32, 390 (1968).

7) Tsujisaka, Y., Iwai, M., Fukumoto, J. and Окамото, Y.: Agr. Biol. Chem., 37, 837 (1973).

8) Nagaoka, K., Yamada, Y. and Koaze, Y. : Agr. Biol. Chem., 33, 299 (1969).

9）仲 恭寛・天野 滋-山下孝二：油化学，35, 459 (1986).

10）山田浩一・町田晴夫・東 俊彦・植田克子：農化 37,645 (1963).

11) Eitenmiller, R.R., VAKIL, J.R. and ShaHANI, K.M.: J. Food Sci., 35, 130 (1970).

(平成 2 年 5 月 1 日受理) 